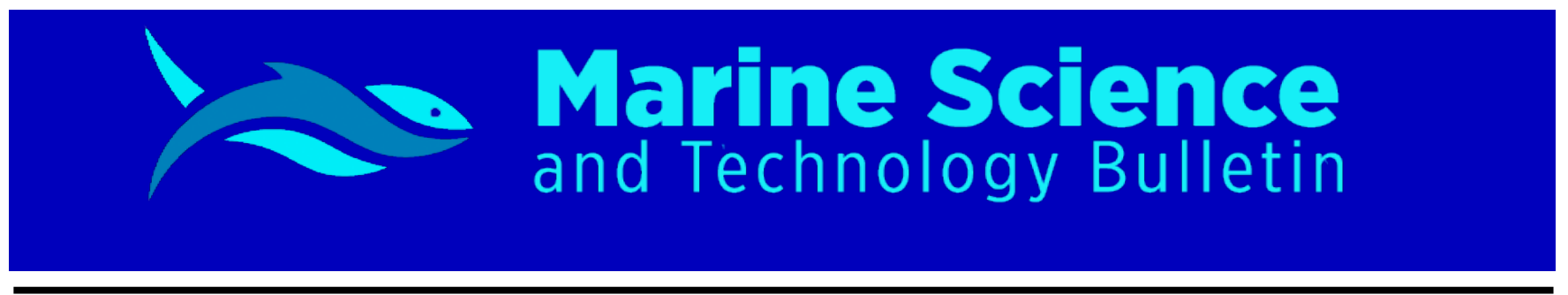

RESEARCH ARTICLE

\title{
A New Maximum Length with Length-Weight Relationship of Tub Gurnard (Chelidonichthys lucerna Linnaeus, 1758) from Central Black Sea
} Coasts of Turkey

\author{
Süleyman Özdemir ${ }^{1^{*}}$ (D) Uğur Özsandıkçı1 ${ }^{1}$ (D) Ferhat Büyükdeveci² (D) \\ ${ }^{1}$ Sinop University, Fisheries Faculty, Sinop, Turkey \\ ${ }^{2}$ Ministry of Agriculture and Forestry, Adana Directorate of Provincial Agriculture and Forestry, Adana, Turkey
}

\section{ARTICLE INFO}

Article History:

Received: 01.11.2019

Received in revised form: 04.12.2019

Accepted: 06.12.2019

Available online: 19.12.2019

Keywords:

Tub gurnard

Length-weight relationship

Coastal fisheries

Black Sea

\begin{abstract}
A B S T RA C T
The study was carried out in the 2012-2016 fishing seasons in the Central Black Sea coasts of Turkey. Tub gurnard (Chelidonichthys lucerna L., 1758) were examined in the commercial fishery (trawls, trammel nets and gillnets). A total of $56.104 \mathrm{~kg}$ tub gurnard was caught during the study period. Total length and weight of 117 tub gurnard individuals were measured. Minimum, maximum and average total lengths were calculated as $12.8 \mathrm{~cm}, 74.2 \mathrm{~cm}$ and $33.28 \pm 1.28 \mathrm{~cm}$, respectively. The maximum length is the second maximum length for the Black Sea coasts however first maximum length for the Central Black Sea coasts of Turkey. Length-weight relationship (LWR) of tub gurnard were determined as $\mathrm{W}=0.0103 \mathrm{~L}^{2.9876}$ in the study. The value of the parameter ' $\mathrm{b}$ ' was found to be 2.9876 and the growth was isometric $(b=3)$ for tub gurnard $(P>0.05)$.
\end{abstract}

Please cite this paper as follows:

Özdemir, S., Özsandıkçı, U., Büyükdeveci, F. (2019). A New Maximum Length with Length-Weight Relationship of Tub Gurnard (Chelidonichthys lucerna Linnaeus, 1758) from Central Black Sea Coasts of Turkey. Marine Science and Technology Bulletin, 8(2): 85-91.

\section{Introduction}

The Black Sea, an almost closed basin between Europe and the Anatolian peninsula, is one of the youngest seas in the world and connected to the Aegean Sea via the narrow Bosphorus and Dardanelles. The Black Sea is a prototypic anoxic sea due to the lack of oxygen in the water, which has existed in the deep for a long time.

\footnotetext{
* Corresponding author

E-mail address: suleymanozdemir57@gmail.com (S. Özdemir)
}

Eukaryotic life occurs in only $10 \%$ of the total depth of the Black Sea (Balkas et al., 1990; Bat et al., 2007; Talley et al., 2011; Bat, 2017).

Tub gurnard (Chelidonichthys lucerna) is one of the three species belong Triglidae family living in the Black Sea (Bat et al., 2008; Bilecenoğlu et al., 2014; Yankova et al., 2014). It is a nectobenthic fish distributed in the eastern Atlantic from Norway to Senegal, Mediterranean and Black Sea (Serena et al., 1998) and mainly habits sand or gravel bottoms up to $320 \mathrm{~m}$ depth (Mytilineou et al., 2005). 
They feed mainly on fish, crustacean and molluscs (Bat et al., 2008). It has been reported that tub gurnard spawn between May and September with 100 000-300 000 pelagic eggs in Georgian coasts of the Black Sea (Komakhidze et al., 2003). This species was classified as least concern in IUCN Red List (Nunoo et al., 2015).

Tub gurnard is mainly caught as by-catch by gill nets and trawls in mixed demersal fisheries for flatfish and round fish (ICES, 2010; Kasapoğlu and Düzgüneş, 2017) and have high commercial value (Bat et al., 2008). Set nets have been used in the Black Sea coastal fishery (Özdemir et al., 2017; Erdem et al., 2018). Target species of these fishing gears are red mullet, whiting, bluefish, horse mackerel and pontic shad (Kalaycı and Yeşilçiçek, 2014; Aydın and Hacıoğlu, 2017). However, some species can be caught by set nets and demersal trawl as economical by-catch for example, tub gurnard, sea bass, sea bream, shi drum, brown meagre and European flounder (Erdem, 2000; Erdem et al., 2007).

Although some biological parameters of tub gurnard have been well-studied in coasts of Sea of Marmara, Aegean Sea, Mediterranean and contiguous Atlantic area (Papaconstantinou, 1984; Colloca et al., 1994; Abdallah, 2002; Santos et al., 2002; Borges et al., 2003; Mendes et al., 2004; İşmen et al., 2004; Eryılmaz and Meriç, 2005; İlhan and Toğulga, 2007; Deval et al., 2007; Boudaya et al., 2008; Çiçek et al., 2008; Vallisneri et al., 2011; Stagioni et al., 2012; Demirel and Dalkara, 2012; Akyol, 2013) the studies in the Black Sea coasts of Turkey are very limited (Ceylan et al., 2014; Haşimoğlu et al., 2016).

Scientific studies are most important for approaching ecosystems sustainable fisheries and success of the fisheries management. It is very essential research on biology, population parameters and lengthweight relationships (LWRs) of all fishes (target, discard and bycatch) in the seas and oceans of the world. Maximum length and weight are important parameters used in life history studies and fishery science. These measurements are applied directly or indirectly in most stock assessment models (Borges 2001; Cengiz et al., 2019a). Therefore, it is important to regularly update the maximum size of commercially important species (Navarro et al., 2012; Cengiz et al., 2019b). LWRs are useful for life history and morphological comparisons of population from different location (Gonçalves et al., 1997; Moutopoulos and Stergiou, 2002).

The aim of the present study is to supply new data on maximum length, length weight relationship (LWR) and fishery of tub gurnard caught in the Central Black Sea coastal fisheries of Turkey.

\section{Material and Methods}

The study was carried out in the Central Black Sea coasts of Turkey at monthly basis by using a commercial demersal trawl (September 2014 - April 2015), trammel nets and gill nets (September 2012 August 2016). The sampling area is Central Black Sea coasts (Sinop inner harbour, Sinop Peninsula and İnceburun off shore) this area is an important migration route of pelagic and demersal school fishes in the Black Sea coasts of Turkey. Samples were collected with demersal trawl at depths ranging from $70 \mathrm{~m}$ to $120 \mathrm{~m}$. Sampling area is shown in Figure 1.

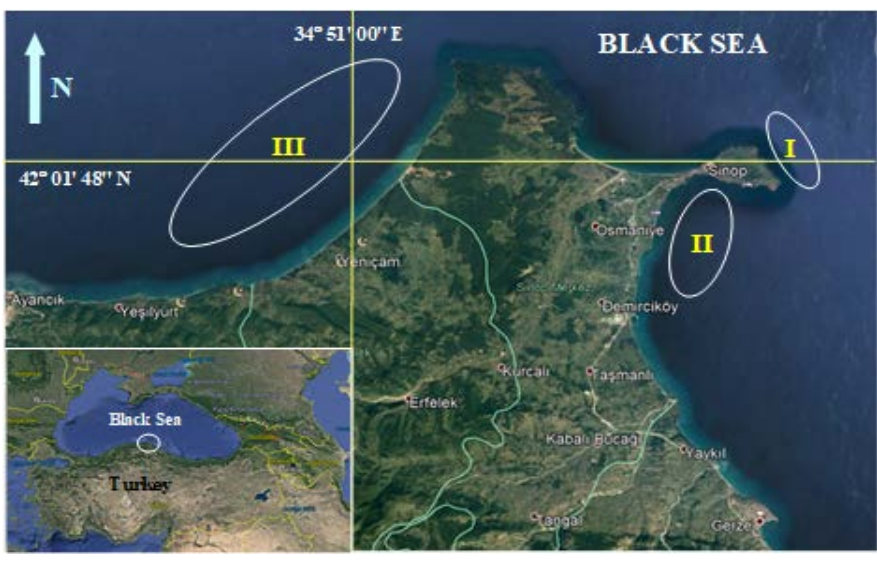

Figure 1. The study areas (I-II: surveys with trammel nets and gill nets, III: surveys with demersal trawls)

Fishes were caught by using a typical otter bottom trawl with 40 $\mathrm{mm}$ codend mesh size; tow duration was restricted to $60-120 \mathrm{~min}$. Also, a total of 18 trammel nets were used with $32 \mathrm{~mm}, 36 \mathrm{~mm}, 40 \mathrm{~mm}$, $44 \mathrm{~mm}, 48 \mathrm{~mm}$ and $52 \mathrm{~mm}$ mesh sizes. Gill nets had $36 \mathrm{~mm}, 44 \mathrm{~mm}$, $48 \mathrm{~mm}$, and $320 \mathrm{~mm}$ mesh size. The fishing gears were used between $15 \mathrm{~m}$ and $60 \mathrm{~m}$ depth.

A total of 22 hauls for trawl and 36 fishing operations for trammel and gill nets were conducted during the study period. Fish were measured to the nearest $0.1 \mathrm{~cm}$ (total length) and weighted to the nearest $0.01 \mathrm{~g}$ (wet weight) (Figure 2).

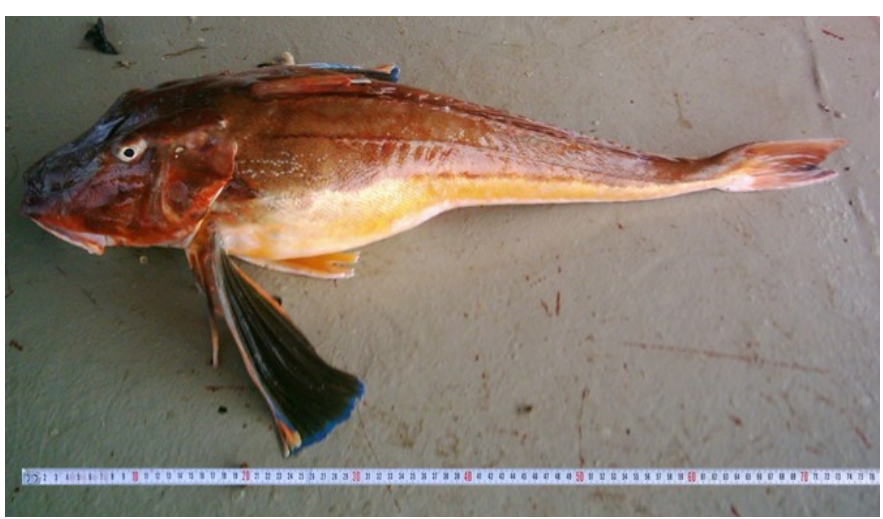

Figure 2. Tub gurnard (Chelidonichthys lucerna L., 1758) captured by demersal trawl net (Maximum length: $74.2 \mathrm{~cm}$ )

Length-weight relationships were estimated by fitting an exponential curve ( $\left.W=a L^{b}\right)$ to the data (Ricker, 1975; Pauly, 1984).

Parameters $a$ and $b$ of the exponential curve were estimated by linear regression analysis over log-transformed data:

$$
\log W=\log a+b \log L
$$

where $W$ is the total weight $(\mathrm{g}), L$ is the total length $(\mathrm{cm}), a$ is the intercept and $b$ is the slope, using the least-squares method. The association-degree between variables of $W$ and $L$ was calculated by the determination coefficient (R). Additionally, 95\% confidence limits of the parameter $b$ were estimated. The Student's $t$ test was used for comparison of the slopes (Zar, 1996).

$$
t=\frac{S d_{\log T L}}{S d_{\log W}} \frac{|b-3|}{\sqrt{1-r^{2}}} \sqrt{n-2}
$$


In this formula, $S d_{\log T L}$ is the standard deviation of the $\log T L$ values, $S d_{\log W}$ is the standard deviation of the $\log W$ values, $n$ is the number of specimens used in the computation. The value of $b$ is different from $b=3$ if calculated $t$ value is greater than the tabled $t$ values for $n$-2 degrees of freedom (Pauly, 1984).

When the parameter ' $b$ ' is statistically equal to 3 , the growth is called isometric, but the growth is positive allometric when the ' $b$ ' value is more than 3 and negative allometric when the ' $b$ ' value is less than 3 (Dutta et al., 2012).

\section{Results}

A total of $56.104 \mathrm{~kg}$ tub gurnard was caught during the study period. Total length and weight of 117 tub gurnard individuals were measured in the study. A total 39 fishes captured by the trawl nets and 78 fishes caught by the trammel nets ( 55 specimens) and gillnets ( 23 specimens).

Minimum, maximum and average total length was calculated as $12.8 \mathrm{~cm}, 74.2 \mathrm{~cm}$ and $33.28 \pm 1.28 \mathrm{~cm}$, respectively. Minimum, maximum and average weight of the fish was recorded as $24.4 \mathrm{~g}, 3983.5$ $\mathrm{g}$ and $532.12 \pm 63.85 \mathrm{~g}$, respectively (Table 1$)$. The largest size fish (74.2 $\mathrm{cm}$ ) captured by the trawl nets in İnceburun off shores (region III) and the smallest fish $(12.8 \mathrm{~cm})$ caught by the trammel nets in Sinop inner harbor region (region II).

Table 1. Length parameters of tub gurnard for the fishing gears $(\mathrm{cm})$

\begin{tabular}{lcccc}
\hline Parameters & Trammel nets & Gill nets & Trawl nets & All \\
\hline Specimens & 55 & 23 & 39 & 117 \\
Minimum & 12.8 & 44.2 & 23.5 & 12.8 \\
Maximum & 55.2 & 68.5 & 74.2 & 74.2 \\
Average & $30.1 \pm 1.37$ & $49.6 \pm 1.44$ & $38.4 \pm 1.32$ & $33.3 \pm 1.28$ \\
\hline
\end{tabular}

Table 2. Length-weight relationship (LWR) parameters for tub gurnard

\begin{tabular}{lc}
\hline \multicolumn{2}{c}{ Parameters } \\
\hline $\mathrm{N}$ & 117 \\
$\mathrm{a}$ & 0.0103 \\
$\mathrm{a}(\mathrm{SE})$ & 0.0647 \\
$95 \%$ Confident of a & $0.0089-0.0142$ \\
$\mathrm{~b}$ & 2.9876 \\
$\mathrm{~b}(\mathrm{SE})$ & 0.0431 \\
$95 \%$ Confident of $\mathrm{b}$ & $2.89102-3.0721$ \\
$\mathrm{R}$ & 0.9884 \\
Growth & Isometric $(\mathrm{b}=3)$ \\
$\mathrm{t}$ test & $\mathrm{p}>0.05$ \\
\hline
\end{tabular}

Note: $N$ is number of specimens; $a$ is intercept of the relationship; $b$ is slope of the relationship; $R$ is coefficient of determination; $b(S E)$ is the standard error of $b ; a(S E)$ is the standard error of $a$.

The fish between the $25 \mathrm{~cm}$ and $35 \mathrm{~cm}$ length group represented the majority of all fish with $59.83 \%$. When the most of fishes were captured in the $35 \mathrm{~cm}$ (31.62\%) length group, the least fish were caught in the $75 \mathrm{~cm}$ (3.42\%) length group. Length-weight relationship (LWR) of tub gurnard was determined as $\mathrm{W}=0.0103 \mathrm{~L}^{2.9876}$. Length-weight frequency distributions and graphic of LWR are shown in Figure 3.

Descriptive statistics on the length and sample size $(n)$, regression parameters $a$ and $b$ of the length-weight relationship (LWR), 95\% confidence intervals of $a$ and $b$, the coefficient of determination (R) of analyzed species are shown in Table 2 .

These results displayed that there was significant relationship between length and weight for tub gurnard. The value of the parameter $b$ was 2.9876 for tub gurnard in the study. The $a$ value of tub gurnard was 0.0143 and coefficient of determination $(\mathrm{R})$ was 0.9884 . The growth was isometric $(b=3)$ for tub gurnard.

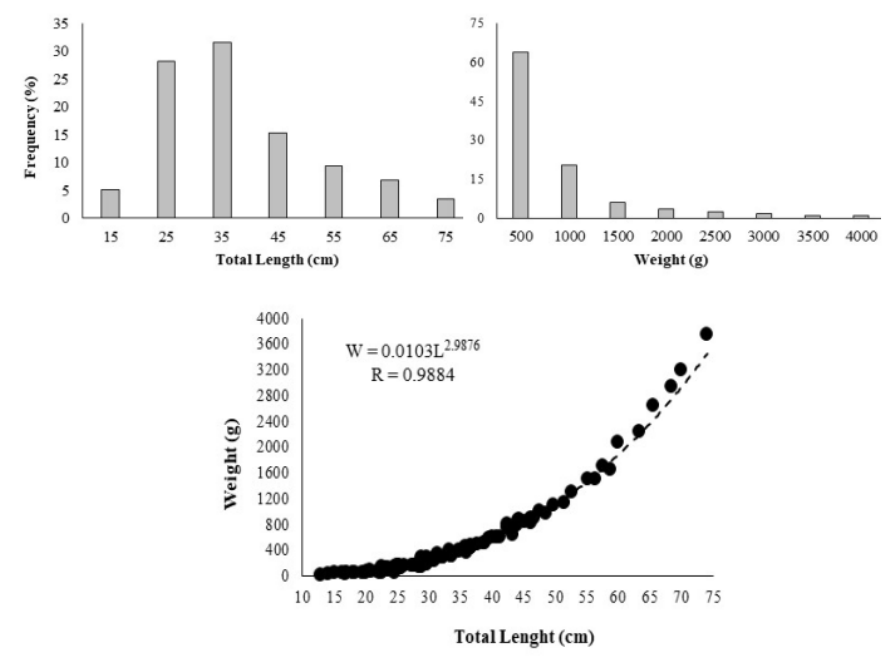

Figure 3. Length-weight frequency distribution and LWR of tub gurnard

\section{Discussion}

The tub gurnard has an important economic value and is important by-catch species in Turkish seas. Many scientists expressed that tub gurnard was captured by trammel nets, gill nets and demersal trawl nets (Özdemir et al., 2003; Çiçek et al., 2006; Ceylan et al., 2014; Kasapoğlu and Düzgüneş, 2017; McCartey and Marriott, 2018).

The present study determined that the mean length and weight are $33.28 \pm 1.28 \mathrm{~cm}$ and $532.12 \pm 63.85 \mathrm{~g}$, respectively. The maximum, minimum total length and weight measured for fishes were $74.2 \mathrm{~cm}$, $12.8 \mathrm{~cm}$, and $24.4 \mathrm{~g}, 3983.5 \mathrm{~g}$, respectively. Minimum and maximum total lengths were reported as $2.2 \mathrm{~cm}$ (Eastern Mediterranean Sea) and $88.2 \mathrm{~cm}$ (Eastern Black Sea) in Turkish seas (Çiçek et al., 2006; Haşimoğlu et al., 2016).

As well known, the individuals in populations exposed to high levels fishing pressure will respond by reproducing at smaller average sizes and ages and so reached maximum lengths may getting and getting smaller. However, the one individual that subjected to no overfishing pressure could be reached that kind of length (Filiz, 2011). On the other hand, any factor that might possibly influence growth has been shown to have an effect, including nutrient availability, feeding, light regime, oxygen, salinity, temperature, pollutants, current speed, nutrient concentration, predator density, intra-specific social interactions and genetics (Helfman et al., 2009; Acarlı et al., 2018). 
Table 3. Studies on parameters of length-weight relationship (LWR) of tub gurnard

\begin{tabular}{|c|c|c|c|c|c|c|c|}
\hline Authors & $\mathbf{N}$ & Sex & $\mathbf{L}_{\text {Max }}-\mathbf{L}_{\text {Min }}$ & $\mathbf{a}$ & $\mathbf{b}$ & $\mathbf{R}$ & Growth \\
\hline \multirow{2}{*}{ aPapacostantinou, $1984^{*}$} & 153 & M & $13.5-76.7$ & 0.007014 & 3.146 & 0.99 & $+\mathrm{A}$ \\
\hline & 122 & $\mathrm{~F}$ & $13.2-32.7$ & 0.007729 & 3.110 & 0.99 & $+\mathrm{A}$ \\
\hline apapacostantinou et al. 1994 & 563 & $\mathrm{M}+\mathrm{F}$ & $6.0-35.0$ & 0.009846 & 3.011 & 0.93 & $-\mathrm{A}$ \\
\hline aSerena et al. 1998 & 538 & $\mathrm{M}+\mathrm{F}$ & $11.7-45.5$ & 0.013900 & 2.859 & 0.99 & $-\mathrm{A}$ \\
\hline aAbdallah, 2002 & 196 & $\mathrm{M}+\mathrm{F}$ & $4.7-24.9$ & 0.029000 & 2.630 & 0.97 & $-A$ \\
\hline aSantos et al. 2002 & 75 & $\mathrm{M}+\mathrm{F}$ & $14.0-34.4$ & 0.018000 & 2.978 & 0.98 & $-A$ \\
\hline aBorges et al. 2003 & 10 & $\mathrm{M}+\mathrm{F}$ & $13.6-29.2$ & 0.001296 & 2.956 & 0.99 & I \\
\hline \multirow{3}{*}{ ȧşmen et al. 2004} & 143 & M & $8.3-21.2$ & 0.089000 & 3.010 & 0.99 & I \\
\hline & 199 & $\mathrm{~F}$ & $8.0-30.3$ & 0.095000 & 3.010 & 0.98 & I \\
\hline & 342 & $\mathrm{M}+\mathrm{F}$ & $8.0-30.3$ & 0.009300 & 2.990 & 0.98 & I \\
\hline 'Eryılmaz and Meriç, 2005 & 224 & $\mathrm{M}+\mathrm{F}$ & $12.3-41.5$ & 0.009200 & 3.019 & 0.98 & I \\
\hline${ }^{\mathrm{a} C ̧ i c ̧ e k ~ e t ~ a l . ~} 2006$ & 137 & $\mathrm{M}+\mathrm{F}$ & $2.2-30.3$ & 0.013500 & 2.851 & 0.99 & $-A$ \\
\hline a Olim and Borges, 2006 & 21 & $\mathrm{M}+\mathrm{F}$ & $7.5-27.7$ & 0.011000 & 2.720 & 0.99 & $-A$ \\
\hline 'İ̇şmen et al. 2007 & 829 & $\mathrm{M}+\mathrm{F}$ & $12.5-76.0$ & 0.009600 & 2.928 & 0.99 & $-A$ \\
\hline \multirow{3}{*}{ bìlhan and Toğulga, 2007* } & 186 & M & $14.1-29.9$ & 0.005300 & 3.237 & 0.98 & $+\mathrm{A}$ \\
\hline & 360 & $\mathrm{~F}$ & $12.7-34.4$ & 0.005100 & 3.245 & 0.98 & $+\mathrm{A}$ \\
\hline & 546 & $\mathrm{M}+\mathrm{F}$ & $12.7-34.4$ & 0.005200 & 3.240 & 0.98 & $+\mathrm{A}$ \\
\hline aSangun et al. 2007 & 474 & $\mathrm{M}+\mathrm{F}$ & $6.7-24.5$ & 0.016600 & 2.743 & 0.97 & $-\mathrm{A}$ \\
\hline \multirow{2}{*}{ aBoudaya et al. 2008} & 126 & M & $17.0-26.0$ & 0.007300 & 3.037 & 0.93 & I \\
\hline & 160 & $\mathrm{~F}$ & $16.0-36.0$ & 0.015500 & 2.826 & 0.95 & $-\mathrm{A}$ \\
\hline bỉlkyaz et al. 2008 & 121 & $\mathrm{M}+\mathrm{F}$ & $12.1-42.3$ & 0.004300 & 3.240 & 0.97 & $+\mathrm{A}$ \\
\hline \multirow{3}{*}{${ }^{\mathrm{a} C ̧ i c ̧ e k ~ e t ~ a l . ~} 2008$} & 106 & M & $6.5-29.3$ & 0.009400 & 2.988 & 0.99 & I \\
\hline & 113 & $\mathrm{~F}$ & $6.1-30.3$ & 0.011400 & 2.918 & 0.99 & $-A$ \\
\hline & 228 & $\mathrm{M}+\mathrm{F}$ & $2.2-30.3$ & 0.012900 & 2.874 & 0.99 & $-\mathrm{A}$ \\
\hline${ }^{\mathrm{C}}$ Keskin and Gaygusuz, 2010 & 17 & $\mathrm{M}+\mathrm{F}$ & $6.3-15.1$ & 0.011300 & 2.902 & 0.98 & I \\
\hline 'Bök et al. 2011 & 90 & $\mathrm{M}+\mathrm{F}$ & $8.0-64.0$ & 0.010000 & 2.982 & 0.98 & I \\
\hline \multirow{2}{*}{${ }^{a}$ Vallisneri et al. 2011} & 396 & M & $12.8-34.2$ & 0.000001 & 2.952 & 0.97 & I \\
\hline & 484 & $\mathrm{~F}$ & $11.3-41.5$ & 0.000001 & 3.038 & 0.98 & I \\
\hline 'Demirel and Dalkıran, 2012 & 352 & $\mathrm{M}+\mathrm{F}$ & $10.5-56.0$ & 0.009000 & 3.000 & 0.98 & I \\
\hline${ }^{b}$ Bilge et al. 2014 & 81 & $\mathrm{M}+\mathrm{F}$ & $16.6-40.7$ & 0.005200 & 3.222 & 0.98 & $+\mathrm{A}$ \\
\hline \multirow{2}{*}{ aEl-Serafy et al. 2015} & 315 & M & $12.6-23.3$ & 0.004300 & 3.264 & 0.97 & $+\mathrm{A}$ \\
\hline & 511 & $\mathrm{~F}$ & $11.8-28.2$ & 0.004200 & 3.265 & 0.98 & $+\mathrm{A}$ \\
\hline ċ̇şmen et al. 2018 & 204 & $\mathrm{M}+\mathrm{F}$ & $9.2-37.0$ & 0.027000 & 2.676 & 0.98 & $-A$ \\
\hline dMcCarty and Marriot, 2018 & 804 & $\mathrm{M}+\mathrm{F}$ & $10.4-57.5$ & 0.067000 & 3.103 & 0.98 & $+\mathrm{A}$ \\
\hline ePresent study & 117 & $\mathrm{M}+\mathrm{F}$ & $12.8-74.2$ & 0.010300 & 2.988 & 0.98 & I \\
\hline
\end{tabular}

Note: $a$ : Mediterranean Sea, $b$ : Aegean Sea, $c$ : Marmara Sea, $d$ : North Sea, $e$ : Black Sea, ${ }^{\star}$ indicates fork length, $M:$ male, $F:$ female, $M+F:$ male and female, Max: maximum, Min: minimum, $I$ : isometric, $+A$ : positive allometric; $-A$ : negative allometric,

The second maximum size for tub gurnard was measured as 74.2 $\mathrm{cm}$ for Black Sea coasts of Turkey. Moreover, this length was the maximum size for this species in the Central Black Sea coasts of Turkey. Maximum lengths were determined as $76 \mathrm{~cm}$ in Aegean Sea, 
$30.3 \mathrm{~cm}$ in Eastern Mediterranean Sea and $64 \mathrm{~cm}$ in Marmara Sea in other studies for Turkish seas (İşmen et al., 2007; Çiçek et al., 2008; Bök et al., 2011). The minimum and maximum lengths were measured in the different countries $6.0 \mathrm{~cm}$ and $57.5 \mathrm{~cm}$, respectively (Papacostantinou et al. 1994; McCartey and Marriot, 2018).

Length-weight relationship was found as $\mathrm{W}=0.0103 \mathrm{~L}^{2.9876}$ $(\mathrm{R}=0.989)$ for tub gurnard (Isometric growth, $b=3(\mathrm{p}>0.05)$ ). In the present study, the $b$ value was estimated to be 2.987 for tub gurnard. It was identified that $b$ values of tub gurnard varied from 2.630 to 3.265 by other authors (Table 1 ). The variations in $b$-values may be ascribed to one or more factors: the seasons and effects of different areas, differences in salinity, temperature and pollution of aquatic environment, gender, nutrient quality and availability, differences in the quantity of fish analyzed, as well as in the observed size ranges of the sampled species (Gonçalves et al., 1997; Froese et al., 2011).

Seventeen of twenty-four studies had significantly different $b$ values, which reported negative allometric growth (Papacostantinou et al., 1994; Serena et al., 1998; Abdallah, 2002; Santos et al., 2002; Çiçek et al., 2006; Olim and Borges, 2006; İşmen et al., 2007; Sangun et al. 2007; Çiçek et al., 2008; Boudaya et al., 2008; İşmen et al., 2018) and positive allometric growth (Papacostantinou, 1984; İlhan and Toğulga, 2007; İlkyaz et al., 2008; Bilge et al., 2014; El-Serafy et al., 2015; McCarty and Marriott, 2018) for tub gurnard. Also, the present study showed that the $b$-values have generally been in agreement with similar results (isometric growth) in seven studies (Table 1).

On the other hand, tub gurnard were generally captured in small sizes. First maturity size of female and male are 19-20 cm and 17-18 $\mathrm{cm}$ for Turkish seas, respectively (İşmen et al., 2004; Eryllmaz and Meriç, 2005; İlhan and Toğulga, 2007). The sizes ranged between 25 $\mathrm{cm}$ and $40 \mathrm{~cm}$ in some studies carried out in other Mediterranean countries (Papacostantinou, 1984; Baron, 1985; McCarty and Marriott, 2018). The minimum landing size (MLS) is $18 \mathrm{~cm}$ for tub gurnard in Turkish seas (Anonymous, 2016). However, it is not enough once for reproductive of fish. The MLS has to be raise for the sustainability of tub gurnard fish stocks in Turkish seas.

\section{Conclusion}

These important data and results are usually used by authorities of fisheries management, scientific institutions and academic studies. Therefore, the relevant studies on fishery, biology, populations and stocks of fish species captured in the Black Sea should be improved and appraised in the future.

Consequently, the tub gurnard is an economic fish for the coastal fishermen, although the fish is captured as by-catch in small scale fisheries in Turkey. Tub gurnard fishery has been decreasing in the Turkish seas for last decade (TurkStat, 2019). For this reason, tub gurnard should not be caught by the fishermen before they reach the first reproduction length $(19 \mathrm{~cm})$. Captured small fishes must be released to the sea once for reproduction. Also, minimum fishing size measure for tub gurnard should be reviewed and the MLS must be raised to more than $18 \mathrm{~cm}$.

\section{Conflict of Interest}

The authors declare that there is no conflict of interest.

\section{References}

Abdallah, M. (2002). Length-weight relationship of fishes caught by trawl off Alexandria, Egypt. Naga, The ICLARM Quarterly, 25(1): 19-20.

Acarlı, D., Kale, S. \& Çakır, K. (2018). A new maximum length for the garfish, Belone belone (Linnaeus, 1761) in the Coast of Gökçeada Island (Aegean Sea. Turkey). Cahiers de Biologie Marine, 59: 385-389.

Akyol, O. (2013). New maximum length of tub gurnard, Chelidonichthys lucerna (Linnaeus, 1758) (Osteichthyes: Triglidae) in the Southern Aegean Sea, Turkey. Journal of Black Sea/Mediterranean Environment, 19(1): 138-142.

Anonymous, (2016). Deniz ve İçsularda Ticari Su Ürünleri Avcılığını Düzenleyen 1/4 Nolu Tebliğ, TGHB, Balıkçılık ve Su Ürünleri Genel Müdürlü̆̆̈̈, 1:112, Ankara.

Aydın, M. \& Hacıoğlu, M.N. (2017). Trabzon Bölgesi’nde Kullanılan Mezgit Uzatma Ağlarının Av Verimi ve Tür Kompozisyonunun Belirlenmesi. Ordu University Journal of Science and Technology, 7(2): 226-238

Balkas, T. (1990). The state of marine environment in the Black Sea region. UNEP Regional Seas Reports and Studies, 124: 41p.

Baron, J. (1985). Les triglides (Teleosteens, Scorpaeniformes) de la baie de Douarnenez, 1. La croissance de Eutrigla gurnardus, Trigla lucerna, Trigloporus lastoviza et Aspitrigla cuculus. Cybium, 9: 127-144.

Bat, L. (2017). Kirlilik ve Balıkçılık. Karadeniz ve Balıkçlık Çalıştayı 13-14 October 2016, Çalıştay Bildiriler Kitabı, 1: 17-54.

Bat, L., Şahin, F., Satılmış, H.H., Üstün, F., Birinci-Özdemir, Z., Kideys, A.E. \& Shulman, G.E. (2007). The changed ecosystem of the black sea and its impact on anchovy fisheries. Journal of FisheriesSciences.com, 1(4): 191-227.

Bat, L., Erdem, Y., Tırıl Ustaoğlu, S. \& Yardım, Ö. (2008). Balık Sistematiği. Nobel Yayın Dağıtım, Ankara, $270 \mathrm{~s}$.

Bilecenoğlu, M., Kaya, M., Cihangir, B. \& Çiçek, E. (2014). An updated checklist of the marine fishes of Turkey. Turkish Journal of Zoology, 38(6): 901-929.

Bilge, G., Yapici, S., Filiz, H. \& Cerim, H. (2014). Weight-length relations for 103 fish species from the Southern Aegean Sea, Turkey. Acta Ichthyologica et Piscatoria, 44(3): 263-269.

Borges, L. (2001). A new maximum length for the snipefish, Macroramphosus scolopax. Cybium, 25(2): 191-192.

Borges, T.C., Olim, S. \& Erzini, K. (2003). Weight-length relationships for fish species discarded in commercial fisheries of the Algarve (Southern Portugal). Journal of Applied Ichthyology, 19(6): 394-396.

Boudaya, L., Neifar, L., Rizzo, P., Badalucco, C., Bouain, A. \& Fiorentino, F. (2008). Growth and reproduction of Chelidonichthys lucerna (Linnaeus) (Pisces: Triglidae) in the gulf of Gabès, Tunisia. Journal of Applied Ichthyology, 24(5): 581-588.

Bök, T.D., Göktürk, D., Kahraman, A.E., Alıçlı, T.Z., Acun, T. \& Ateş, C. (2011). Length-weight relationships of 34 fish species 
from the Sea of Marmara, Turkey. Journal of Animal and Veterinary Advances, 10(23): 3037-3042

Cengiz, Ö., Kızılkaya, B. \& Paruğ, Ş.Ş. (2019a). Maximum size record of brown meagre (Sciaena umbra Linnaeus, 1758) for Aegean Sea. KSU Journal of Agriculture and Nature, 22(4): 659-663.

Cengiz, Ö., Kızılkaya, B. \& Paruğ, Ş.Ş. (2019b). Growth characteristics of annular seabream (Diplodus annularis Linnaeus, 1758) for Turkish Waters. KSU Journal of Agriculture and Nature, 22(5): 817-822.

Ceylan, Y., Şahin, C. \& Kalayci, F. (2014). Bottom trawl fishery discards in the Black Sea coast of Turkey. Mediterranean Marine Science, 15(1): 156-164.

Çiçek, E., Avşar, D., Yeldan, H. \& Özütok, M. (2006). Length-weight relationships for 31 teleost fishes caught by bottom trawl net in the Babadıllimanı Bight (Northeastern Mediterranean). Journal of Applied Ichthyology, 22: 290- 292.

Çicek, E., Avşar, D., Özyurt, C.E., Yeldan, H. \& Manaşırlı, M. (2008). Age, growth, reproduction and mortality of tub gurnard (Chelidonichthys lucernus (Linnaeus, 1758)) inhabiting in Babadillimani Bight (North-eastern Mediterranean coast of Turkey). Journal of Biological Sciences, 8(1): 155-160.

Colloca, F., Ardizzone, G.D. \& Gravina, M.F. (1994). Trophic ecology of gurnards (Pisces: Triglidae). Marine Life, 4(2): 45-57.

Demirel, N. \& Dalkara, E.M. (2012). Weight-length relationships of 28 fish species in the Sea of Marmara. Turkish Journal of Zoology, 36(6): 785-791.

Deval, M.C., Bök, T., Ateş, C. \& Özbilgin, H. (2007). Size selectivity of three diamond mesh codends for the European hake (Merluccius merluccius) and the tub gurnard (Trigla lucerna) in the Sea of Marmara, Turkey. Journal of Applied Ichthyology, 23(2): 167-172.

Dutta, S., Maity, A., Chanda, A., Akhand, A. \& Hazra S. (2012). Length weight relationship of four commercially important marine fishes of Northern Bay of Bengal, West Bengal, India. Journal of Applied Environmental Biological Sciences, 2: 52-58.

El-Serafy, S., El-Gammal, F.I., Mehanna, F.S., Abdel-Hamid, N.H. \& El-Sayed Farrag, F.E. (2015). Age, growth and reproduction of the tub gurnard, Chelidonichthys lucerna (Linnaeus, 1758) from the Egyptian Mediterranean waters off, Alexandria. International Journal of Fisheries and Aquatic Sciences, 4(1): 13-20.

Erdem, Y. (2000). Karadeniz şartlarında yerli dip trolü ile İtalyan dip trolünün av verimi ve seçicilik gücü yönünden karşılaştırılması. Su Ürünleri Sempozyumu Sinop 2000 Bildiriler Kitabı, 1: 316-236.

Erdem, Y., Özdemir, S., Erdem, E. \& Birinci-Özdemir, Z. (2007). Dip trolü ile iki farklı derinlikte avlanan mezgit (Gadus merlangus euxinus N. 1840) balı̆̆ının av verimi ve boy kompozisyonunun değişimi. Türk Sucul Yaşam Dergisi, 35(3-4): 395-400.
Erdem, Y., Özdemir S., Özsandıkçı, U. \& Büyükdeveci, F. (2018). Fishery infrastructures of Sinop province. Turkish Journal of Maritime and Marine Sciences, 4(1): 20-30.

Eryılmaz, L., \& Meriç, N. (2005). Some biological characteristics of the tub gurnard, Chelidonichthys lucernus (Linnaeus, 1758) in the Sea of Marmara. Turkish Journal of Veterinary and Animal Sciences, 29(2): 367-374.

Filiz, H. (2011). A new maximum length for the red mullet, Mullus barbatus Linnaeus, 1758. BIBAD - Research Journal of Biological Sciences, 4: 131-135.

Froese, R., Tsikliras, A.C. \& Stergiou, K.I. (2011). Editorial note on weight-length relations of fishes. Acta Ichthyologica et Piscatoria, 41: 261-263.

Gonçalves, J.M.S., Bentes, L., Lino, P.G., Ribeiro, J., Canário, A.V.M. \& Erzini, K. (1997). Weight-length relationships for selected fish species of the small-scale demersal fisheries of the South and South-west coast of Portugal. Fisheries Research, 30: 253-256.

Haşimoğlu, A., Ak, O., Kasapoğlu, N. \& Atılgan, E. (2016). New maximum length report of Chelidonichthys lucerna (Linneaus, 1758) in the Black Sea, Turkey. Journal of Black Sea/Mediterranean Environment, 22(2): 149-154.

Helfman, G.S., Collette, B.B., Facey, D.E. \& Bowen, B.W. (2009). The diversity of fishes: Biology, evolution, and ecology. WileyBlackwell, West Sussex, UK. 720 pp.

ICES (2010). Report of the Working Group on Assessment of New MoU Species (WGNEW), 11-15 October 2010, ICES HQ, Denmark. ICES CM 2010/ACOM: 21: 185 pp

İlhan, D. \& Toğulga, M. (2007). Age, growth and reproduction of tub gurnard Chelidonichthys lucernus Linnaeus, 1758 (Osteichthtyes: Triglidae) from İzmir Bay, Aegean Sea, Eastern Mediterranean. Acta Adriatica, 48(2): 173-1984.

İlkyaz, A.T., Metin, G., Soykan, O. \& Kinacigil, H.T. (2008). Lengthweight relationship of 62 fish species from the Central Aegean Sea, Turkey. Journal of Applied Ichthyology, 24(6): 699-702.

İşmen, A., İşmen, P. \& Başusta, N. (2004). Age, growth and reproduction of Tub Gurnard (Chelidonichthys lucerna L. 1758) in the Bay of Iskenderun in the Eastern Mediterranean. Turkish Journal of Veterinary and Animal Sciences, 28(2): 289-295.

İşmen, A., Özen, O., Altınağaç, U., Özekinci, U. \& Ayaz, A. (2007). Weight-length relationships of 63 fish species in Saros Bay, Turkey. Journal of Applied Ichthyology, 23: 707-708.

İşmen, A., İnceoğlu, H., Arslan İhsanoğlu, M., Yığın, C.Ç., Çardak, M., Daban, B. Kocabaş, E., Özer, Z., Kara, A., Şirin, M. \& Öktener, A. (2018). Length-weight relationships and abundance distribution of Triglidae species caught by beamtrawl in the Sea of Marmara. COMU Journal of Marine Science and Fisheries, 1(1): 13-19.

Kalaycı, F. \& Yeşilçiçek, T. (2014). Influence of season, depth and mesh size on the trammel nets catch composition and discard in 
the Southern Black Sea, Turkey. Marine Biology Research, 10: 824-832.

Kasapoğlu, N. \& Düzgüneş, E. (2017). The common problem in the Black Sea fisheries: By-catch and its effects on the fisheries economy. Turkish Journal of Fisheries and Aquatic Sciences, 17: 387-394.

Keskin, Ç. \& Gaygusuz, Ö. (2010). Length-weight relationships of fishes in shallow waters of Erdek Bay (Sea of Marmara, Turkey). IUFS Journal of Biology, 69(1): 25-32.

Komakhidze, A., Diasamidze, R. \& Guchmanidze, A. (2003). State of the Georgian Black Sea demersal ichthyo resources and strategy for their rehabilitation and management. In: Workshop on Demersal Resources in the Black Sea and Azov Sea (Eds. B. Öztürk and S. Karakulak). Turkish Marine Research Foundation, İstanbul, Turkey. 14: 93-103.

McCarthy, I.D. \& Marriott, A.L. (2018). Age, growth and maturity of tub gurnard (Chelidonichthys lucerna Linnaeus 1758; Triglidae) in the inshore coastal waters of Northwest Wales, UK. Journal of Applied Ichthyology, 34(3): 581-589.

Mendes, B., Fonseca, P. \& Campos, A. (2004). Weight-length relationships for 46 fish species of the Portuguese west coast. Journal of Applied Ichthyology, 20(5): 355-361.

Moutopoulos, D.K. \& Stergiou, K.I. (2002). Length-weight and length-length relationships of fish species from the Aegean Sea (Greece). Journal of Applied Ichthyology, 18: 200-203.

Mytilineou, C., Politou, C.Y., Papaconstantinou, C., Kavadas, S., D'Onghia, G. \& Sion, L. (2005). Deepwater fish fauna in the Eastern Ionian Sea. Belgium Journal of Zoology, 135(2): 229233.

Navarro, M.R., Villamor, B., Myklevoll, S., Gil, J., Abaunza, P. \& Canoura, J. (2012). Maximum size of Atlantic mackerel (Scomber scombrus) and Atlantic chub mackerel (Scomber colias) in the Northeast Atlantic. Cybium, 36(2): 406-408.

Nunoo, F., Poss, S., Bannermann, P. \& Russell, B. (2015). Chelidonichthys lucerna. The IUCN Red List of Threatened Species: e.T198752A15597014. Retrieved on November 1, 2019 from http://dx.doi.org/10.2305/IUCN.UK.20154.RLTS.T198752A15597014.en

Olim, S. \& Borges, T.C. (2006). Weight-length relationships for eight species of the family Triglidae discarded on the south coast of Portugal. Journal of Applied Ichthyology, 22: 257-259.

Özdemir, S., Sümer, Ç. \& Erdem, Y. (2003). Farklı Materyale Sahip Fanyalı Solungaç Ağlarının Av Verimleri ve Av Kompozisyonunun Karşılaştırılması. XII. Ulusal Su Ürünleri Sempozyumu Bildiriler Kitabı, 1: 467-472.

Özdemir, S., Özsandıkçı, U., Erdem, Y. \& Büyükdeveci, F. (2017). Sinop kıyılarında kullanılan fanyalı uzatma ağlarına hedef dışı yakalanan yengeç türlerinin av kompozisyonu. Türk Denizcilik ve Deniz Bilimleri Dergisi, 3(2): 55-62.

Papaconstantinou, C. (1984). Age and growth of the yellow gurnard (Trigla lucerna L. 1758) from the Thermaikos Gulf (Greece) with some comments on its biology. Fisheries Research, 2(4): 243-255.

Papaconstantinou, C., Politou, C.Y., Caragistou, E., Stergiou, K.I., Mytilineou, C., Vassilopoulou, V., Fourtouni, A., Karkani, M., Kavadas, S., Petrakis, G., Siapatis, A., Chatzinikolaou, M. \& Giagnisi, M. (1994). Investigations on the abundance and distribution of demersal stock of primary importance in the Thermaikos Gulf and the Thracian Sea (Hellas). National Centre for Marine Research, Athens, Hellas Technical Report North Aegean Sea Series, 4: 356 pp.

Pauly, D. (1984). Fish Population dynamics in tropical waters: a manual for use with programmable calculators. ICLARM Studies and Reviews, Manila, Philippines. 8: 325.

Ricker, W.E. (1975). Computing and interpretation of biological statistics of fish populations. Bulletin of the Fisheries Research Board of Canada, 191: 382.

Sangun, L., Akamca, E. \& Akar, M. (2007). Weight-length relationships for 39 fish species from the North-Eastern Mediterranean coast of Turkey. Turkish Journal of Fisheries and Aquatic Sciences, 7: 37-40.

Santos, M.N., Gaspar, M.B., Vasconcelos, P. \& Monteiro, C.C. (2002). Weight-length relationships for 50 selected fish species of the Algarve coast (southern Portugal). Fisheries Research, 59(1-2): 289-295.

Serena, F., Voliani, A. \& Auteri, R. (1998). Nursery areas and some biological information of tub gurnard (Trigla lucerna L., 1758) off Tuscany coasts (Italy). Rapp. Comm. int. Mer. Medit, (CIESM) 35: 482-483.

Stagioni, M., Montanini, S. \& Vallisneri, M. (2012). Feeding of tub gurnard Chelidonichthys lucerna (Scorpaeniformes: Triglidae) in the north-east Mediterranean. Journal of the Marine Biological Association of the United Kingdom, 92(3): 605-612.

Talley, L.D., Pickard, G.L., Emery, W.J. \& Swift, J.H. (2011). Gravity waves, tides, and coastal oceanography: Supplementary materials. Descriptive Physical Oceanography (Sixth Edition). Academic Press, Boston, pp. 1-31.

TurkStat (2019). Turkish Fishery Statistics 2018. Turkish Statistical Institute. Retrieved on November 30, 2019 from https://biruni.tuik.gov.tr/medas/?kn=97\&locale $=\operatorname{tr}$

Vallisneri, M., Stagioni, M., Montanini, S. \& Tommasini, S. (2011). Body size, sexual maturity and diet in Chelidonichthys lucerna (Osteichthyes: Triglidae) from the Adriatic Sea, north eastern Mediterranean. Acta Adriatica: International Journal of Marine Sciences, 52(1): 141-147.

Yankova, M., Pavlov, D., Ivanova, P., Karpova, E., Boltachev, A., Öztürk, B., Bat, L., Oral, M. \& Mgeladze, M. (2014). Marine fishes in the Black Sea: recent conservation status. Mediterranean Marine Science, 15(2): 366-379.

Zar, J.H. (1996). Biostatistical Analysis. 3rd ed. Prentice-hall: Englewood Cliffs, NJ. 662 p. 